\title{
PENGGUNAAN GADGET DAN SEDENTARY BEHAVIOUR PADA ANAK USIA PRASEKOLAH DI TAMAN KANAK-KANAK AISYAH BUSTANUL ATHFAL III PARE
}

\section{USAGE OF GADGETS AND SEDENTARY BEHAVIOURS IN CHILDREN AGE PRESCHOOL IN AISYAH BUSTANUL ATHFAL III KINDERGARTEN PARE}

\author{
Linda Ishariani ${ }^{1^{*}}$, Laviana Nita Ludyanti ${ }^{2}$ \\ ${ }^{1,2}$ Sekolah Tinggi Ilmu Kesehatan Karya Husada Kediri \\ *Korespondensi Penulis: isharianilinda@gmail.com
}

\begin{abstract}
Abstrak
Penggunaan gadget menyebabkan perubahan pola, gaya hidup serta aktivitas terutama pada anak usia prasekolah. Anak yang bermain gadget cenderung lebih banyak diam dan asyik dengan gadgetnya. Hal ini akan menyebabkan anak menjadi kurang bergerak (sedentary behaviour). Tujuan dari penelitian ini adalah menganalisa hubungan penggunaan gadget dan sedentary behavior pada anak prasekolah di Taman Kanak-Kanak Aisyah Bustanul Athfal III Pare. Penelitian ini menggunakan desain penelitian korelasional dengan pendekatan cross sectional. Teknik pengambilan sampel menggunakan purposive sampling. Jumlah sampel penelitian ini sebanyak 45 responden. Variabel independen dalam penelitian ini adalah penggunaan gadget, dan variabel dependennya adalah sedentary behavior. Data dikumpulkan dengan menggunakan kuesioner dan dianalisa denganan menggunakan uji Spearman Rho. Penelitian menunjukkan bahwa penggunaan gadget sebagian besar dalam kategori sedang dan sedentary behavior dalam kategori berat. Hasil uji Spearman's Rho didapatkan $\mathrm{p}=0,002$ maka H0 ditolak, hal ini menunjukkan ada hubungan antara penggunaan gadget dan sedentary behavior. Nilai koefisien korelasi $\rho=0,457$ maka ada hubungan positif sedang antara penggunaan gadget dan sedentary behavior. Saran untuk orangtua agar selalu mendampingi anak dalam bermain dan memberikan aktivitas yang sesuai untuk tumbuh kembang anak.
\end{abstract}

Kata kunci: penggunaan gadget, sedentary behavior, anak prasekolah

\begin{abstract}
The use of gadgets will cause changes patterns, lifestyles and activity in preschoolers. Children who play gadgets tend to be quiet and fixed toward their gadgets, and affect child to become less activity (sedentary behavior). The purpose of this study was to analyze the relationship between the use of gadgets and sedentary behavior in preschoolers in Aisyah Bustanul Athfal III Pare Kindergarten. This study was a correlational research design with cross sectional approach. The sampling technique used was purposive sampling. The number of samples of this study were 45 respondents. The independent variable in this study is the using of gadgets, and the dependent variable is sedentary behavior. Data were collected using a questionnaire and analyzed using the Spearman Rho test. The results show that the use of gadgets is mostly in the moderate category and sedentary behavior in the heavy category. Spearman's Rho test resulting $p=0.002$ means there is a relationship between gadget usage and sedentary behavior. Correlation coefficient value $\rho=$ 0.457 then there is a moderate positive relationship between the use of gadgets and sedentary behavior. The use of gadgets is related to sedentary behavior which is influenced by the child's sex, parental work and changes in behavior patterns. Suggestions for parents to always accompany children while playing and provide activities appropriate for child development.
\end{abstract}

Keywords: gadget using, sedentary behavior, preschool 


\section{Pendahuluan}

Saat ini perkembangan teknologi mencapai titik dimana hanya dengan satu sentuhan tombol semua bisa terpenuhi dan tersedia. Bekerja, belajar, belanja dan hiburan dapat kita dapat melakukan banyak hal. Perkembangan teknologi ini dirasakan oleh semua kelompok usia, termasuk pada anak usia sekolah. anak usia prasekolah sudah mulai mengenal gadget dan menggunakannya. Teknologi mengubah cara dan pola hidup masyarakat dan anak-anak, terutama pada anak usia prasekolah.

Usia prasekolah merupakan usia anak cepat mengalami pertumbuhan dan perubahan pola kebiasaan sehari-hari (Tanjung, 2017). Masa prasekolah merupakan masa dimana aktivitas fisik meningkat dan kebutuhan bermain juga meningkat. Pada masa ini anak-anak yang seharusnya bermain dengan menggunakan aktivitas yang tinggi, seperti berlari tetapi kini anak-anak cenderung bermain yang menggunakan aktivitas fisik yang ringan/ rendah seperti bermain gadget.

Gadget merupakan suatu alat teknologi pintar yang memiliki tujuan dan fungsi yang spesifik, salah satunya sebagai alat komunikasi yang berukuran semakin kecil sehingga mudah dibawa, praktis, ringan dan tidak membutuhkan banyak tempat dan banyak energi.

Penggunaan gadget akan menyebabkan perubahan pola serta gaya hidup terutama pada anak usia prasekolah. Anak prasekolah merupakan masa untuk pertumbuhan yang pesat dan masa mereka mengeksplorasi lingkungan dengan bermain. Anak akan cenderung lebih banyak diam dan asyik dengan bermain gadget. Hal ini akan menyebabkan anak menjadi kurang bergerak (sedentary behaviour) (Manumpil, 2015). Bermain gadget merupakan salah satu bentuk aktifitas fisik tidak aktif yang diistilahkan dengan sedentary lifestyle (Hmustaq, 2011).

Penelitian Heni (2018) mengemukakan penggunaan smartphone pada anak usia prasekolah sebanyak $72,7 \%$ dalam kategori sering. Hasil penelitian Tanjung (2017) mengemukakan penggunaan gadget pada anak usia prasekolah pada penelitian di Yogyakarta sebanyak $77,2 \%$ dalam kategori tinggi. Penelitian yang dilakukan Ishariani (2019) di TK Dharma Wanita Pare Kediri didapatkan penggunaan gadget pada anak usia prasekolah sejumlah $60 \%$ dalam kategori sedang.
Laporan Riset Kesehatan Dasar tahun 2013 tersebut menunjukkan bahwa proporsi aktivitas fisik tergolong kurang aktif secara umum adalah 26,1 persen. Terdapat 22 provinsi dengan penduduk aktivitas fisik tergolong kurang aktif berada diatas rata-rata Indonesia. Hasil penelitian Vale, dkk menunjukkan adanya gaya hidup yang menetap terjadi di awal tahapan tumbuh kembang yaitu usia 0-5 tahun. Pada tahuntahun awal anak-anak menghabiskan 73\%-84\% dari waktu bangun mereka dengan perilaku kurang gerak. Pada tahun-tahun awal, sebagian besar anak-anak menghabiskan lebih dari 1 jam per hari berada di depan layar (screen time) dan melakukan kegiatan berbasis layar sebelum usia 2 tahun. Menurut Owen (2010) durasi waktu harian yang dihabiskan untuk menatap layar disebut screen time. Rata-rata lama penggunaan tersebut terdapat 4 hingga 6 di antara 10 anak usia prasekolah sudah sangat lekat dengan tayangan televisi maupun aplikasi di gadget, sehingga beresiko mengalami kecanduan ${ }^{11}$.

Sedentary behaviour merupakan perilaku yang terjadi saat duduk atau berbaring yang membutuhkan pengeluaran energi yang sangat rendah, seperti duduk atau berbaring sambil menonton televisi, bermain game elektronik, membaca, dan lain sebagainya. Dampak yang dapat ditimbulkan dari sedentary behaviour diantaranya adalah gangguan kardiometabolik, gangguan respirasi (asma), gangguan psikososial (cemas, depresi, harga diri rendah) dan termasuk juga gangguan pertumbuhan dan perkembangan (Setyoadi, 2015).

Gaya hidup sedentary sering mengabaikan aktivitas fisik dan lebih banyak melakukan kegiatan yang tidak membutuhkan banyak energi. Saat ini pengalihan waktu yang biasa dilakukan anak-anak untuk bermain aktif diluar rumah menjadi aktivitas duduk pasif di depan layar komputer, televisi maupun gadget. Sedentary behaviour dapat menimbulkan efek negatif bagi kesehatan terutama pada pertumbuhan anak. Anak yang berperilaku kurang gerak (sedentary behaviour) cenderung untuk tidak melakukan aktivitas sehingga terdapat timbunan lemak dan anak mengalami peningkatan berat badan dan obesitas. Tujuan dari penelitian ini adalah menganalisa hubungan penggunaan gadget dan sedentary behavior. 


\section{Metode}

Penelitian ini menggunakan desain penelitian Korelasional dengan pendekatan cross sectional. Penelitian ini digunakan untuk mengidentifikasi penggunaan gadget dan perilaku sedentari (sedentary behavior) di TK ABA III Pare Kediri. Populasi dalam penelitian ini adalah semua ibu dan siswa TK ABA III Pare Kediri.

Sampel dalam penelitian ini adalah ibu dan siswa TK ABA III Pare Kediri yang memenuhi kriteria inklusi sejumlah 45 responden. Teknik pengambilan sampel dalam penelitian ini menggunakan purposive sampling. Variabel independen dalam penelitian ini adalah penggunaan gadget, dan variabel dependennya adalah Sedentary behaviour. Sebagai instrumen untuk pengumpulan data adalah kuesioner.

Penelitian dilakukan pada bulan Mei 2019. Proses penelitian dilakukan setelah memperoleh ijin Ketua LPPM dan Kepala Sekolah TK ABA III. Responden yang telah terpilih akan diberikan penjelasan tentang tujuan dan manfaat penelitian dan diberikan informed consent selanjutnya diberikan kuesioner tentang penggunaan gadget dan sedentary behaviour. Data yang terkumpul diolah dan dianalisa dengan menggunakan uji korelasi Spearman Rho dengan tingkat kemaknaan 0,05.

\section{Hasil}

Karakteristik responden yang meliputi usia ibu, pendidikan ibu, pekerjaan, usia anak, jenis kelamin anak, anak ke-, adalah sebagai berikut:

Tabel 1. Karakteristik Responden

\begin{tabular}{|c|c|c|c|}
\hline & Kategori & Frekuensi & $\begin{array}{l}\text { Prosentase } \\
(\%)\end{array}$ \\
\hline \multirow[t]{3}{*}{ Usia Ibu } & 20-30 tahun & 14 & 31,11 \\
\hline & $31-40$ tahun & 24 & 53,33 \\
\hline & $>40$ tahun & 7 & 15,56 \\
\hline \multirow{4}{*}{$\begin{array}{l}\text { Pendidikan } \\
\text { Ibu }\end{array}$} & $\mathrm{SD}$ & 2 & 4,44 \\
\hline & SMP & 4 & 8,89 \\
\hline & SMA & 29 & 64,44 \\
\hline & PT & 10 & 22,22 \\
\hline \multirow{6}{*}{$\begin{array}{l}\text { Pekerjaan } \\
\text { Ibu }\end{array}$} & IRT & 28 & 62,22 \\
\hline & Wiraswasta & 4 & 8,89 \\
\hline & Swasta & 6 & 13,33 \\
\hline & Guru & 5 & 11,11 \\
\hline & Tani & 1 & 2,22 \\
\hline & Perawat & 1 & 2,22 \\
\hline \multirow{2}{*}{$\begin{array}{l}\text { Jenis } \\
\text { Kelamin } \\
\text { Anak }\end{array}$} & Laki-laki & 21 & 46,67 \\
\hline & Perempuan & 24 & 53,33 \\
\hline Usia Anak & 4 tahun & 5 & 11,11 \\
\hline
\end{tabular}

\begin{tabular}{llll} 
& 5 tahun & 21 & 46,67 \\
& 6 tahun & 19 & 42,22 \\
\hline Jumlah & Tidak punya & 8 & 17,78 \\
saudara & 1 & 20 & 44,44 \\
kandung & 2 & 11 & 24,44 \\
& 3 & 5 & 11,11 \\
& 4 & 1 & 2,22 \\
\hline
\end{tabular}

Tabel 1 menjelaskan bahwa responden ibu, sebagian besar berusia 30-40 tahun sebanyak $53,33 \%$. Pendidikan ibu paling banyak adalah SMA, ditunjukkan sebesar 64,44\%. Pekerjaan responden paling banyak adalah sebagai ibu rumah tangga (IRT) sebesar 62,22\%. Sedangkan jenis kelamin anak lebih banyak perempuan sebesar 53,33\%. Usia anak pra sekolah yang paling banyak berusia 5 tahun sebesar 46,67\%. Jumlah saudara kandung yang paling banyak sebanyak 1 saudara yang ditunjukkan dengan prosentase sebesar $44,44 \%$.

Tabel 2. Distribusi frekuensi responden berdasarkan penggunaan gadget

\begin{tabular}{|l|c|c|}
\hline $\begin{array}{c}\text { Penggunaan } \\
\text { gadget }\end{array}$ & Frekuensi & Prosentase (\%) \\
\hline Ringan & 5 & 11,1 \\
\hline Sedang & 23 & 51,1 \\
\hline Berat & 17 & 37,8 \\
\hline
\end{tabular}

Hasil penelitian tentang penggunaan gadget didapatkan penggunaan gadget pada anak usia prasekolah paling banyak dengan kategori sedang sejumlah 23 responden dengan prosentase sebesar $51,1 \%$.

Tabel 3. Distribusi frekuensi responden berdasarkan sedentary behaviour (perilaku sedentari)

\begin{tabular}{|l|l|l|}
\hline \multicolumn{1}{|c|}{$\begin{array}{c}\text { Perilaku } \\
\text { sedentari }\end{array}$} & \multicolumn{1}{|c|}{ Frekuensi } & Prosentase (\%) \\
\hline Ringan & 6 & 13,3 \\
\hline Sedang & 17 & 37,7 \\
\hline Berat & 22 & 49 \\
\hline
\end{tabular}

Hasil penelitian tentang sedentary behaviour didapatkan perilaku sedentari pada anak usia prasekolah didapatkan hampir setengah dari responden perilaku sedentari dalam kategori berat sejumlah 22 responden dengan prosentase sebesar $49 \%$.

Adapun hubungan antara penggunaan gadget dan sendentary behavior diolah dengan statistik menggunakan uji Spearman's Rho, dengan hasil sebagai berikut:

Tabel 4. Hasil analisa Penggunaan gadget dan 
sedentary behaviour

\begin{tabular}{lll}
\hline & $N$ & Sig (2-tailed) \\
\hline Spearman's Rho & 45 & 0,002 \\
\hline
\end{tabular}

Hasil uji Spearman's Rho untuk mengetahui penggunaan gadget dan perilaku sedentary didapatkan basil $p$-value (nilai sig.) sebesar 0,002 dengan $\alpha<0,05$, yang berarti terdapat hubungan antara penggunaan gadget dengan sedentary behaviour.Nilai koefisien korelasi $\rho=0,457$ maka ada hubungan positif antara penggunaan gadget dan sedentary behavior dengan tingkat korelasi sedang.

\section{Pembahasan}

Hasil penelitian menunjukkan penggunaan gadget pada anak prasekolah paling banyak dalam kategori sedang $(51,1 \%)$. Hasil penelitian Mulyati (2018) bahwa perempuan memiliki rata-rata kecanduan smartphone $(82,25)$ lebih tinggi dari pada laki-laki (77,92): Penelitian yang lain dikemukakan oleh Choliz (2012), yang menyatakan bahwa perempuan memiliki tingkat ketergantungan smartphone lebih tinggi dibandingkan dengan laki-laki, perempuan lebih sering menggunakan smartphone daripada laki-laki, perempuan juga lebih cenderung terlibat dalam penyalahgunaan smartphone. Pada penelitian ini didapatkan $53,33 \%$ perempuan, perempuan cenderung lebih banyak menggunakan waktunya di dalam rumah daripada bermain diluar rumah, sehingga anak perempuan lebih banyak menggunakan waktunya untuk bermain gadget daripada bermain diluar.

Faktor yang lain yang mempengaruhi penggunaan gadget adalah pendidikan ibu yang sebagian besar berpendidikan SMA $(64,4 \%)$. Melalui pendidikan orangtua seharusnya bisa memahami dampak suatu hal seperti gadget bagi anak, tetapi ibu-ibu justru memberikan anaknya gadget agar anak tidak ketinggalan dan bisa mengikuti perkembangan tetapi mereka tidak melihat dampak negatif bagi anaknya. Hal ini tidak sesuai dengan teori yang dikemukan Budiman (2013) bahwa pendidikan mempengaruhi proses belajar, semakin tinggi pendidikan semakin mudah menerima informasi dan semakin tinggi pengetahuan.
Perilaku sedentari pada anak dari hasil penelitian didapatkan bahwa 49\% anak mengalami perilaku sedentari kategori berat. Penelitian Dupuy, et all (2011), anak lebih banyak melakukan aktivitas yang kurang mengeluarkan energi dan bahkan justru memilih aktivitas yang berbasis layar Pada penelitian ini, pekerjaan ibu paling banyak sebagai ibu rumah tangga. Ibu merasa kegiatan mengatur rumah tangga membutuhkan waktu yang banyak. Ibu cenderung membiarkan anak untuk bermain sendiri supaya anak lebih tenang. Hal ini menjadi sebuah kesempatan bagi anak untuk lebih memilih bermain gadget, menonton televisi atau bermain dengan media berbasis layar lainnya..

Faktor yang lain disebabkan oleh jumlah saudara kandung. Paling banyak responden hanya memiliki 1 saudara kandung $(24,4 \%)$. Anak tidak memiliki banyak teman untuk diajak bermain yang bisa mengeluarkan energi yang banyak, yang pada akhirnya anak cenderung untuk bermain yang tidak banyak mengeluarkan energi hanya dengan menonton televisi atau bermain gadget.

Faktor perubahan gaya hidup juga berpengaruh dengan perilaku sedentari, dimana ibu mengikuti perubahan gaya hidup dengan mengganti aktivitas fisik anak dengan memfasilitasi anak untuk menonton TV, main game dan internet. Kegiatan ini tidak lepas dari sosial ekonomi orangtua. Hal ini sesuai dengan teori Tembley (2011) bahwa anak dari sosial ekonomi yang tinggi memiliki gaya hidup merubah aktivitas fisik dengan nonton $\mathrm{TV}$, game dan internet.

Hasil analisa data penggunaan gadget dan sedentary behaviour menurut uji Spearman Rho didapatkan $\mathrm{p}=0,002$ artinya ada hubungan antara penggunaan gadget dengan sedentary behaviour. Hal ini disebabkan oleh aktivitas anak-anak yang menggunakan gadget dalam waktu yang lama, mereka akan lebih banyak duduk, berbaring dan kurang melakukan aktivitas yang banyak mengeluarkan energi sehingga anak menjadi kurang bergerak (perilaku sedentari).

Arundhana (2013) mengemukakan adanya televisi, komputer dan internet sebagai bentuk kemajuan teknologi menyebabkan anak malas untuk bergerak. Kemajuan tersebut menimbulkan berbagai bentuk kemudahan (TV, gadget, komputer) sehingga 
menyebabkan penurunan aktifitas fisik dan meningkatkan sedentary behaviour pada anak.

Penggunaan alat elektronik berupa komputer, video game maupun gadget dapat menyebabkan penurunan aktifitas fisik pada anak sehingga meningkatkan perilaku sedentary (Kemenkes, 2012). Intensitas waktu bermain gadget dan video game merupakan salah satu penyebab perilaku sedentary pada anak prasekolah (Vandewater, 2004).

American Academy of Pediatrics (AAP) merekomendasikan durasi penggunaan media berbasis layar untuk anak tidak lebih dari 1-2 jam perhari. Pada kenyataannya anak-anak banyak menggunakan waktunya hanya untuk bermain gadget lebih dari 3 jam perhari.

\section{Kesimpulan}

1. Penggunaan gadget pada anak prasekolah didapatkan sebagian besar dalam kategori sedang.

2. Sedentary behaviour yang dialami oleh anak usia prasekolah hampir setengahnya dalam kategori berat.

3. Penggunaan gadget berhubungan dengan sedentary behaviour.

\section{Saran}

Disarankan pada orangtua untuk memilih dan mendampingi anak dalam bermain serta mengontrol anak dalam penggunaan gadget. Orangtua perlu memberikan kegiatan yang bisa membantu anak untuk aktif dan banyak bergerak serta dapat menstimulasi pertumbuhan dan perkembangan anak.

\section{Ucapan Terima Kasih}

Ucapan terima kasih disampaikan kepada STIKES Karya Husada Kediri dan TK Aisyah Bustanul Athfal III yang membantu dalam kelancaran proses penyusunan penelitian ini.

\section{Daftar Pustaka}

American Academy of Pediatrics Committe on Public Education Children. 2001. Adolescence and Television. Pediatr.

Arundhana AI, Hadi H, Julia M. 2013. Perilaku sedentari sebagai faktor risiko kejadian obesitas pada anak sekolah dasar di Kota Yogyakarta dan Kabupaten Bantul. J Gizi dan Diet Indonesia;1(2):71-80

Budiman, Riyanto. 2013. Kapita Selekta Kuesioner Pengetahuan dan Sikap dalam Penelitian Kesehatan. Salemba Medika. Jakarta

Choliz, M. 2012. Mobile-phone Addiction in
Adolescence: the test of mobile phone dependence, (TMD). Prog Health Sci, 2(1)

Dupuy, M. Godeau, E. Vignes, C and Ahluwalia, N. 2011. Sosiodemographic and lifestyle factor associated with Overweight in a Representative sample of 11-15 Year Olds in France.

Heni. 2018. Pengaruh Penggunaan Smartphone terhadap Perkembangan Personal Sosial Anak Usia Prasekolah. Jurnal Keperawatan Silampasi 2 (1)

HMustaq MU,Gull S, Mustaq K, Shahid U, Shad MA.2011. Dietary Behaviors, Physical Activity and Sedentary Lifestyle Associated with Overweight and Obesity and their Socio-demographic Correlatetes, among Pakistani Primary School Children. Int.J.Behav.Nutr.Phys Act.8(1):130

Ishariani L, 2019. Penggunaan Gadget dengan Perkembangan Mental Emosional Anak Usia Prasekolah. Jurnal Ilkes. 10(2)

Kemenkes RI. 2012. Pedoman Pencegahan dan Penanggulangan Kegemukan dan Obesitas pada Anak. Kemenkes. Jakarta.

Manumpil B. 2015. Hubungan Penggunaan Gadget dengan Tingkat Prestasi Siswa. Universitas Samratulangi 3:1-6

Mulyati. 2018. Kecanduan Smartphone ditinjau dari Kontrol Diri dan Jenis Kelamin pada Siswa SMA Mardisiswa Semarang. Jurnal Empati. 7(4): 152-161

Owen N, Healy GN, Mattehws CE, Dunstan DW. 2010. Too Much Sitting; The Population Health Science of Sedentary Behavior. Exerc Sci Rev. 38: 105-113

Saputri. 2018. Dampak Penggunaan Gadget terhadap Kemampuan Interaksi Sosial Anak Usia Dini, Proseding of The 3rd Annual Conference on Islamic Early Childhood Education.

Setyoadi. 2015. Hubungan Penggunaan Waktu Perilaku Kurang Gerak (Sedentary Behavior) dengan Obesitas pada Anak Usia 9-11 tahun di SD Negeri Beji 02 Tulungagung. Jurnal Ilmu Keperawatan Universitas Brawijaya $3(2)$

Tanjung. 2017. Intensitas Penggunaan Gadget pada Anak Prasekolah yang kelebihan berat badan di Yogyakarta. BKM Journal of Community Medicine and Public Health 3(12) :603-608

Temblay,M.S. Leblanc,A.G. Janssen,I. Kho,M.E. Hicks,A. Muruments,K. Colley,R.C dan Dugan,M. 2011. Canadian Sedentary Behavior Guidelines for Children \& Youth. Apply Physiol Nutr.Metab. 36 (1):59-64

Vandewater,E.A, Shin,M.S. Caplovitz,A.G. 2004. Linking Obesity and Activity Level with Children's Television and Video Gae Use J. Adolescence 27 (1): 71-85 